\title{
A Genealogy of Trees and Flesh
}

\section{Jack Matthews}

There is not a drop of blood in my veins that does not come from some British line or other, and yet I-along with my paternal line of fathers for generations back-have the dark skin and hawk features of an American Indian. ${ }^{1}$ Originally, my ancestors came to this country from England, early in the eighteenth century. They were Quaker ironsmiths-brothers-and they landed in Virginia.

They must have had moments of strange recognition when they gazed upon some of the Indians they met. They must have sensed a physical kinship, or at least the simulacrum of one, in the lighter-skinned Indians they saw. There is an old legend that the Mandans, a western tribe exterminated by small pox before the Civil War, were eponymous descendants of Madoc, the Welsh explorer. Some of their women even had blue eyes and beautiful silver hair, as revealed in the portraits of George Catlin.

The similarity seems to be more than superficial. It is said that both Celtic peoples and the American Indians have a larger than normal representation among them of people with $\mathrm{O}$ and $\mathrm{O}$ Negative blood types. People with this type of blood, I have read, tend to be clannish, emotional and secretive. Part of their deepest mechanism of mind and body is set against the regimented and the overly socialized. It is their fate, I suspect, to see the darkness that surrounds every light, and to feel insidious hatreds and resentments, so that they whisper, "No," amidst cries of asseveration.

But my subject at this moment is not the Indians, but my own Celtic, and pre-Celtic Iberian ancestors. The Indians come to mind not only because of the chemical, psychological and physical likenesses mentioned above, but also because the Indians-as my ancestors knew them-along with my ancestors themselves, have vanished. Because of this, they no longer have literal and practical effect; but they are, for this same reason, vested with mythical power.

Existence precedes essence; and like a lot of people, I have spent a great deal of my waking life searching for, and striving to define and create, my es-

1 They say that the physical appearance of the poet Tennyson, for example, was representative of this old type of Briton. There are, of course, many others, both famous and unknown. 
sence. It is such a passion as this-a deeply philosophical one, in spite of the ridicule of "modernist" thinkers (the quotation marks should really bracket the second word) . . . it is preeminently a philosophical passion to know one's antecedents, as if they were temporal causes; and it is this that takes one to the written traces of the past, and the study of genealogy. It is of deep importance to know one's family, if only to understand what one must resist in his inheritance.

It was this motive that took me to a hundred archives, with the hope that I might better understand the dark and mysterious people whose lives had eventuated in mine. And after a great deal of study, I dreamed of one. Or perhaps I should say, one of them came to me in a dream.

But before relating the details of this visit, I will make one more observation: while existence precedes the essential, it is dream that precedes the quintessential. The deepest heart of what we are exists only on the other side of light, and we have access to it only in dreams. It is this $O$ Negative Celt in me that says this to you.

I didn't know his name, and I had no idea of what remote relationship he bore to me. I only sensed that I was somehow a direct descendant of him . . . a lineal descendant, although I knew that this fact alone did not necessarily mean I carried any of his genes in my body.

But this idea does not fit the occasion. An older idea-the mystic kinship of "blood" (only partially witnessed by the chemistry I have mentioned) is the relevant one here, and thus the true one. There is no doubt: this man and I were tied together, no matter how tenuously, across the centuries. We meant something to each other, and this something was both elemental and inexpressible.

At first, he was simply sitting there before me, looking at me. He was very dark, and seemed incredibly old. He wore clothing of some sort, but this was all out of focus-like something deliberately blurred in a photograph.

He was looking at me, and repeating a single word: "betrayed."

"What betrayal?" I asked him.

He shook his head no. And then I heard heavy birds flying overhead, their wings clapping like distant gunfire. Also in the distance, I heard something like a surf rising and collapsing upon some unseen beach. Perhaps it was breathing.

"I don't think you could understand," he said.

When he said this, I noticed that there was a wand of some sort in his hand. Of course, he was a tree worshiper; and possibly this was mistletoe or hazel. But the leaves were unclear, and when I tried to fix my gaze on them, they would begin to spread like some kind of dye, staining the air.

"What I have heard," he said, "is this. You went out into the woods and selected a tree. Without ceremony or compunction, you picked this tree out. Without understanding or fear."

"You cut the tree down," he continued, shaking his head no, and waving his wand back and forth, "and then you mutilated it-cut it up into rectangular boards. Didn't you know that rectangles are symbolic of arrogance? Didn't you know what sacrilege you were committing?"

I laughed at this man, but I don't think he could hear or see. It was as if my laugh were blown away by a wind. I was sure, then, that he couldn't see me 
any more clearly than I could see him. Could it be, I have wondered, that I was also visiting him in a dream?

"Then you took the two largest boards," he continued, "and mortised them, and fitted them into a large cross. This, of course, was blasphemy. The cross was meant to symbolize a man, it is true, but more importantly it was meant to symbolize the tree it had once been! Do you realize the arrogance in the act? To take this once living tree, kill and mutilate it, and then in mockery put it back into the simplified, rectilinear shape of a tree!"

He nodded several times in silence, and then said, "Yes, I have heard all this. I know all about your betrayals. Don't try to answer."

I started to laugh again, and started to explain that he was using the wrong pronoun-it wasn't "your"-but I decided not to. It was obvious he was half blind. This was the best interpretation. Also, I think that-even at this time-I had a suspicion that this was nothing but a dream. The stuff at the heart of ultimate essence, perhaps; but not to be taken literally or seriously in itself. I think, given our human evasiveness and genius for the irrelevant, that it might be the deepest and ultimately most powerful truths from which we have least to fear. They are irrelevant, and of the dream. It's what you mix with the dream that makes it powerful or silly. (Some day I will write a treatise on the chemistry of dreams, which is as powerful as the chemistry of blood.)

"Suppose it were the other way?" he asked, holding his hands palm upward, as if to weigh an intangible surmise in them. "Suppose a man were killed, and then mutilated-his limbs torn off and his trunk carved into slabs of meatand then they were to put him together again? Even with a smile on the face of the corpse? Wouldn't this mock what he had been? Wouldn't it?"

I cried out to him then that this was exactly what we did, now. That we cut their bodies open, instead of slicing their limbs off, but that we tried to create their corpses into an image of sleep, so that silly old women would look in a casket and say, "He looks peaceful, doesn't he? Just as if he were asleep!"

"Your fire was better!" I cried.

I don't know whether he heard or not. But if my outburst had not altered his state of mind (if I can speak of it in that way) it nevertheless altered mine. I was sympathetic with him, suddenly; and this sympathy no longer had to do exclusively with the deep tide of blood that pulled us with the same ancient systolic force.

"Yes," he said (answering himself, I am sure). "Yes. An abomination to that tree, and a cursing of the god of life that thrust it upwards toward the sun and moon and stars, in the gesture of saying yes."

"The tree?" I asked.

"Yes," he repeated, but still not clearly answering my question.

I could hear a wind blowing in the limbs above us, then, and for a few minutes we were silent, but then his eyes grew wide and terrible, and he said, "But there was still more. You took that mocking simulacrum of a tree and nailed it to a man!"

What could I say to such a misunderstanding? After this utterance, the wind increased and the dream itself ended in turmoil and darkness. 
Still, I don't think I will forget it. Something in us says that every idea must have a voice, that even the most fantastic connections between events must be expressed. That even the most ridiculous notions must be heard.

So I have written about it. Partially in honor of those dead tree worshippers who sometimes still, it seems, speak to us, or come to us in sleep and confound our expectancies and our oblivion.

They are almost voiceless, and any witness they bear must be heard.

Why do I insist upon this?

Sometimes I dream of Indians wandering on the plain, in a long tenuous line. They raise dust. Their dogs and women chatter and bark, but the old warriors are silent.

Until the first approaches me, and points at hideous scars on his face, and I know what he means.

He looks like my fathers, and he looks like me.

In the distance, I think I can hear trees whispering.

But I don't always want to hear.

The plains Indians buried their dead upon scaffoldings, standing like geometric groves upon the dry earth, so that the wolves could not mutilate the flesh of the corpses.

I see these, too, in my dreams.

Everything, you must understand, is evidence.

It is the $\mathrm{O}$ Negative Celt in me that tells you this. 